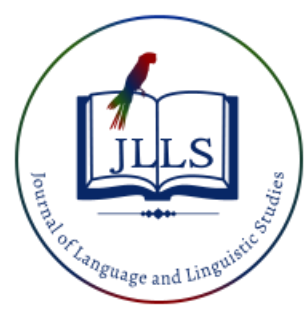

\title{
The effectiveness of visual materials in teaching vocabulary to deaf students of EFL
}

\author{
Fatma Gülengül Birinci a 1 iD, Arif Sariçoban b iD \\ ${ }^{a}$ Hacettepe University, Ankara, Turkey \\ ${ }^{b}$ Selçuk University, Konya, Turkey
}

\author{
APA Citation: \\ Birinci, F. G., \& Sarıçoban, A. (2021). The effectiveness of visual materials in teaching vocabulary to deaf students of EFL. Journal of \\ Language and Linguistic Studies, 17(1), 628-645. Doi: 10.52462/jlls.43 \\ Submission Date:20/12/2020 \\ Acceptance Date:25/02/2021
}

\begin{abstract}
This study aims to investigate the effectiveness of using visual materials in teaching vocabulary to deaf students of EFL. For this purpose, 80 deaf students from a state special education vocational high school in Turkey contributed to this study. All students had first English classes in their lives and they are at the starter level of English, thus pre-test for their English proficiency was not given. The students were randomly divided into two groups to form the experimental group and the control group. 10 vocabulary items per week were taught to the students, and 50 target vocabulary items in total were taught during the whole study. To the experimental group, the vocabulary items were taught via visual materials together with the sign language. The control group was not presented with any visual items during the teaching process of the experiment, only sign language instruction was used for them. After the treatment, a vocabulary test was given to each group as an immediate post-test to measure the impact on learning. Six weeks after the immediate tests, delayed post-test was given to the groups to test long term retention. The results of the two post-tests were analyzed through Independent Samples t-test and Paired Samples t-test calculations to investigate the effectiveness of visual materials. According to the results of the study, visual materials were found to be more effective than using only the sign language that does not contain any visual items in teaching vocabulary items to deaf learners who learn English as a foreign language.
\end{abstract}

Keywords: deaf students; vocabulary teaching; visual materials; foreign language teaching

\section{Introduction}

Deafness is a kind of impairment in hearing which is so severe that the deaf individuals cannot process linguistic information through hearing properly. Their educational performances are influenced negatively by this hearing impairment. Lip-reading is occasionally used by some deaf children to communicate orally, but most of them often use their national sign languages as their primary means of communication. Visually transmitted sign patterns are used to convey meaning in sign languages. All sign languages in the world have their own complex spatial grammars, and these

The findings of this study rely on the data collected by the first author's MA thesis supervised by Prof. Dr. Arif Sarıçoban.

${ }^{1}$ Corresponding author.

E-mail Address: gulengul@ hacettepe.edu.tr 
grammars are completely different from the grammars of other spoken languages. Moreover, all sign languages have manual alphabets used with finger spelling (Pfau, Steinbach \& Woll, 2012). Technical vocabulary items and proper names are represented mostly by finger spelling, and it can also be used when the individual does not know the sign language equivalent for the item. All countries have their own sign languages used mostly by hearing impaired and deaf individuals. Turkish sign language is used in Turkey and it obtained its legal recognition in 2015.

Sign languages are considered to be the native language of the deaf and most of hard of hearing children. Thus, acquiring some forms of spoken languages will be second and third language acquisition of these children. Deaf learners' English learning shares some similarities with hearing L2 learners' English learning, but learning English for deaf learners is more challenging because of the difficulties they face. For example, owing to not hearing and speaking even in their mother tongue, some language skills such as speaking and listening are omitted from their curriculum. In addition, deaf learners have difficulties in learning abstract items, and also in writing and reading efficiently.

In today's world, learning English tend to be vital for all people including deaf people as it is lingua franca. The necessity of learning English for deaf or hard of hearing students is also clarified by Berent and Clymer (2007) as "In non-English-speaking countries the numbers of deaf students entering postsecondary degree programs at colleges and universities are rapidly increasing. Due to the prominent role of English as an international language, students must satisfy English language course requirements in order to develop the skills to access English-language academic materials, the World Wide Web (www), and other resources" (p. 5).

Vocabulary knowledge is very significant in learning a foreign language. Without learning its vocabulary, no one can learn a foreign language. Mastering target vocabulary items is essential to communicate and form sentences in the target language. According to Pohl (2003), "Teachers may wonder why it is important to teach vocabulary. First of all, comprehension improves when you know what the words mean. Secondly, words are the currency of communication. Last but not least, when children and adolescents improve their vocabulary, their academic and social confidence and competence improve, too" (p. 5). Hence, teaching target vocabulary items should be given the importance it deserves by language teachers in the teaching process. Learning English vocabulary is also crucial for deaf learners of English in non-English-speaking countries because these learners can only acquire the linguistic structures, writing and reading skills, and and it is nearly impossible to acquire these skills totally without adequate vocabulary knowledge. According to Fowlkes (2009), "one prevalent area of difficulty is vocabulary in teaching deaf students" (p. 2). Vocabulary provides the basis of a language and it directly influences an individual's life in all facets. It is also the building block for literacy. Therefore, deaf students, as all other students, should be taught vocabulary items effectively. Nevertheless, deaf students need so many repetitions to understand and use the words properly and communicatively. Therefore, teaching vocabulary to deaf and hard of hearing students can be regarded as a struggle. Second language acquisition of English will also be limited for these students on account of restricted auditory access and the need to rely heavily on compensatory visual input (Berent and Clymer, 2007) although it is clear that sign languages provide visual representations of vocabulary items for deaf.

In Turkey, the curricula of special education schools do not include compulsory English courses for deaf students because authorities suppose that they cannot learn foreign languages, and there is no study about this subject in the literature. Thus, this study aims to investigate the effectiveness of visual materials together with the sign language in teaching English vocabulary to deaf students in Turkey, and to contribute the awareness of authorities that they can learn foreign languages. 


\subsection{Literature review}

\subsubsection{Deafness and language acquisition}

People who are deaf or hard of hearing have also the ability to learn languages; however, language learning processes are not identical with the process of hearing people. As Chomsky's innate hypothesis claims, for language learning individuals have innate capacity irrespective of being blind or deaf. Although all people can learn languages, people with disabilities can learn more tardily than healthy people. Particularly hearing impaired individuals have many difficulties in learning languages since they do not have auditory input. For learning a language, it is obvious that listening first is crucial. Nevertheless, deaf people cannot receive this auditory input, so the acquisition and learning processes are naturally different from their hearing peers. Deaf and hearing impaired people can acquire even their mother tongue through different ways such as gestures, sign language, finger spelling, etc. It means that these people can acquire their native language only through visual modality (Fromkin, Rodman, \& Hyams, 2011). Furthermore, it's possible for some deaf and hard of hearing people to place cochlear implants in the inner ear, and it gives them an opportunity to hear. However, the age at which it is placed is so significant for their language acquisition.

An individual's physical ability to produce sounds or native intelligence are not affected by the inability to hear. Deaf people do not have a good academic performance in general, yet their intelligence is not associated to this fact. Kirk and Gallagher (1989) rightly put it, "deaf children have normal cognitive abilities and their poor academic performance actually stems from their difficulty in reading and writing the English language, not their intelligence" (p. 312). When the people acquire their mother tongue, they need to listen and imitate the sounds they hear to be able to speak. Because of not hearing the sounds, most of the deaf students cannot speak properly like hearing peers, and this fact influences their academic performance in a negative way. However, people who lost the ability to hear after their first language acquisition often have the ability to speak properly, and therefore they can show better academic performance. Additionally, some deaf and hard of hearing people may also have speech impairments. Except for these children with speech impairment, teachers had better use the spoken language together with the sign language in communicating with deaf students in order not to prevent their speech developments as well.

Deaf and hearing impaired people should be evaluated under their own circumstances in terms of the language development. These people cannot obtain auditory input as other hearing people, and this case influences their language development in a bad way. McCoy and Masterman (1997) clarify these challenges by stating, "Perhaps the worst difficulty for the deaf learner is that $\mathrm{s} / \mathrm{he}$ has little or no understandable input in the language s/he is attempting to acquire" (p. 48). Dimling (2007) also states, "hearing loss has its greatest effect on the ability to communicate, often due to inaccessibility of verbal language. Resulting from this loss, the linguistic model is incomplete, and a normally spoken message may be distorted" (p. 11). Correspondingly, he adds "Many students with hearing loss are delayed in language development, which can lead to further complication in literacy achievement" (p. 5). As known, for deaf and hard of hearing people, it is almost impossible to communicate effectively like hearing people. These people will not have the same literacy development as hearing people's. As Berent and Clymer (2003) accomplish, "For deaf students, restricted linguistic access to auditorybased languages such as English, Russian, Czech, etc., often results in lower-than-desired levels of spoken-language literacy. These low literacy levels can have serious negative effects on the educational and career attainments of deaf individuals" (p. 2).

There are various factors that influence the language development of deaf individuals such as hearing or deaf parents and the age at which hearing impairment occurs. Deaf children who have deaf parents are advantageous than those of hearing parents. Importance of parents' roles in acquisition 
process is a vital fact especially for first language acquisition. In this respect, deaf children of deaf parents are prosperous since they are born to parents who already know the sign language, so they will not have communication problems with their parents. Fromkin et al., (2011) describe this fact as "Deaf children who are born to deaf signing parents are naturally exposed to sign language just as hearing children are naturally exposed to spoken language. Language development in these deaf children parallels the stages of spoken language acquisition" (p. 355). However, deaf children of hearing parents have serious problems as they are different from their parents. Their parents usually do not exactly know how to support their language acquisition. As for these children, it is so hard to acquire a language, and it is maybe an everlasting process. Nonetheless, it cannot be considered as impossible, which supports the biological basis of the language acquisition in humans. According to Fromkin et al., (2011) "Deaf children of hearing parents who are not exposed to sign language from birth suffer a great handicap in acquiring language. It may be many years before these children are able to use a spoken language or before they encounter a conventional sign language. Yet the instinct to acquire language is so strong in humans that these deaf children begin to develop their own manual gestures to express their thought and desires" (p. 356). These gestures can be seen as the sign of humans' impressive drive to communicate. Similarly, Malmker (1995) claims, "Not all deaf people have the opportunity to acquire sign language from birth because many of them are born to hearing parents who do not know sign language, and because the use of sign language has been discouraged in the past" (p. 545). This detained exposure of linguistic input can be regarded as the reason for their linguistic inabilities, and this deferment of language development definitely affects their literacy developments. As Wilbur (2000) clarifies, "By the time hearing children begin to learn to read, they already have conversational fluency in their native language and can be taught to transfer this knowledge to reading. Deaf children who have lost their hearing at an early age do not have this knowledge; thus, they do not come to the reading task with the same skills in sentence formation, vocabulary and world knowledge as hearing children" (p. 82). Therefore, teachers and parents of deaf or hard of hearing children should support their language acquisitions as much as possible. Otherwise, their literacy developments, which are also crucial for academic achievement, will profoundly be influenced by their delayed language development.

Language development of deaf people is also affected by the age at which hearing impairment occurs. This factor is also claimed by Lenneberg's Critical Age Hypothesis (1967). The deaf can be categorized into two categories in terms of the age of hearing loss as Pre-lingual and Post-lingual. It is called as pre-lingual if hearing impairment occurs before the acquisition of a language. It is approved by many researchers that language acquisition is very easy in the first few years of life due to the elasticy of the children's brain. This critical and open period ends approximately at the age of six. If deafness prevents this opportunity for learning in this critical period, language learning in the usual way is almost impossible. It is nearly impossible for pre-lingually deaf people to acquire a language as others because they are deprived of any auditory language input. On the other hand, it is called as postlingual if hearing loss occurs after the acquisition of the native language. These post-lingually deaf people can have some aural/oral communication problems, but they do not have a language problem. Their language skills can be almost identical with hearing persons hinging on the age of the hearing loss. However, they will still have a delay in learning new idioms of the language. Speech reading instruction and hearing aids are usually very beneficial for these post-lingually deaf people (Charrow \& Fletcher, 1973).

\subsubsection{Deafness and foreign (third) language acquisition}

In countries where English is not the mother tongue of the people, the first language of deaf people is usually a sign language, and their third language often becomes their foreign language, which is generally English. For example, deaf people in Turkey usually learn English as a foreign and third 
language. Dotter (2008) notifies that "Taking a sign language as the first or preferred language of deaf people, a written/spoken national one is already their second language; any other written/spoken language becomes the third one. As there is very little instruction on structure/grammar of sign languages for many deaf people, it is difficult for them to grasp all the linguistic information on a second or third language. English, the lingua franca of the European community, therefore, in the best case is the third language of deaf people" (p. 100). In today's global world, mastering a foreign language is a necessity for all hearing and deaf people to be able to communicate with people in other countries, and to be able to use information technology tools effectively as well. Today, the foreign language of people in non-English speaking countries is generally English because of being lingua franca. Cole (as cited in Bidoli \& Ochse, 2008) explains the reasons for learning a foreign language as the following;

- "learning about different cultures,

- communicating with different people,

- $\quad$ getting a better understanding of one's own language, and

- having better opportunities in the job market" (p. 179).

Nevertheless, as for English speaking countries, the situation is not the same since in these countries, English is the second language of deaf people, not their foreign language. As Macurova (2004) clarifies, "The specific circumstances of English teaching to the deaf in English-speaking countries differ from those in non-English speaking countries, the differences also affect such aspects as the orientation and goals of the teaching process" (p. 31). Therefore, it is a proven fact that teaching deaf and hard of hearing people must be evaluated and judged in its own merit because they have a unique language acquisition and learning process.

Many researchers admit that the development of skills in the third language is influenced by the skills previously acquired in the first and the second language. The deaf individuals can transfer the literacy skills which are developed in the majority language to their third (foreign) language (Martin, 2009). Therefore, the acquisition of the second language has a great effect on their foreign language. Deaf children of deaf parents generally have better cognitive skills in their first language acquisition, so they can be considered as the most advantageous group. Moreover, if language teachers of these deaf people also know the their first (visual) language, they can help the acquisition process more. As Hyjánková (2010) states "Knowledge of sign language in all its aspects can help especially the language teachers of deaf to find the best approaches enhancing the teaching of the second or the third language with respect to a mother tongue or the first language of the deaf - sign language" (p. 21).

Many factors such as cognitive style, motivation, learning styles, learning strategies and affective filter have been discussed by linguists so far as the elements of better learning process in foreign language learning. As for deaf individuals there are various considerations besides these factors. Martin (2009) explains these factors as the following: Firstly, "The degree and onset of hearing impairment are one of the key factors determining the peculiarities of the process of language acquisition and indeed language learning" (p. 32). Both hearing people and people with hearing impairments have almost the same opportunities thanks to the advances in amplification technology, and some of them may even notice the auditory input. Secondarily, "The hearing status of parents, being directly related to the question of family language, seems to have a definite impact on primary language acquisition and thus on the general language learning abilities" (p. 33). That is to say, deaf children of deaf parents are noticeably superior to deaf children of hearing parents in terms of the ability to learn languages. Furthermore, the quality, quantity and penetrability of foreign language input are the key issues for efficient third/foreign language learning of deaf and hard of hearing people. As a result, it should be kept in mind that if appropriate techniques and methods are utilized, deaf 
people can also learn spoken or written foreign languages. Hilzensauer and Skant (2004) carried out a pilot study and has proved this fact. In the study, a computer-assisted program which is called as Signon! has been developed. Its primary objective is to support deaf people to use the computerized learning materials which can be used in the classroom context autonomously. With sign language instruction, the program provides videos, sign translations, multiple repetitions which cannot be done at the classroom settings and lots of visual elements all of which support deaf learners to process the foreign language input. Thanks to these facilities, deaf students can use their target language efficiently (Bidoli \& Ochse, 2008). As a consequence, it is understood as long as the necessary precautions and regulations are taken by language teachers of deaf people in the teaching process and special attention they need is considered, deaf people can learn foreign languages in despite of their lack of hearing. Thus, language teachers should give special attention in teaching and organize the teaching setting regarding their different needs, and also utilize appropriate teaching methods and techniques which are composed of visual elements in order to help them process the foreign language input.

\subsubsection{Significance of vocabulary knowledge in foreign language teaching for deaf}

Languages comprise many components such as vocabulary knowledge, grammar, listening, speaking, reading and writing skills. In some cases, grammar can be considered as the most essential component, but it is a certain fact that one cannot communicate effectively and naturally in a language without adequate vocabulary knowledge. Exclusively in foreign language teaching, vocabulary knowledge can be seen as the core aspect even from the starter levels. Vocabulary knowledge is also vital for an effective reading comprehension as it is nearly impossible to understand what they read without knowing the meaning of words. In addition to reading, an adequate vocabulary always helps learners communicate more efficiently. In sum, neither a limited amount of vocabulary nor minimal knowledge of structures is covetable (Celce-Murcia and Rosensweig, 1989). As Flohr (2008) clarifies "In order to be able to speak in a foreign language properly, students need to learn vocabulary because otherwise they will not be able to express and articulate themselves in a way that other students or native speakers of English can understand them" (p. 2). Thus, in foreign language learning, vocabulary is very significant aspect, and it links to four basic language skills: listening, reading, speaking and writing. Sufficient vocabulary knowledge is a must rather than a choice in order to have these four language skills. As Wilkins (1972) epitomizes, "without grammar very little can be conveyed, without vocabulary nothing can be conveyed" (p. 111).

Especially for deaf and hard of hearing learners, vocabulary knowledge gains more importance due to the fact that it is one of the restricted things they can learn in a foreign language. There are various studies which claim that the vocabulary knowledge of deaf or hard of hearing students who is quantitatively less and more limited than their hearing peers. To put it more clearly, it is an obvious fact that deaf or hard of hearing students are also quite late in acquiring vocabulary and so they acquire fewer lexicons. Besides, they learn new vocabulary items at slower rates, and they have a narrower range of contexts that result in vocabulary learning (Lucker and Cooke, 2010). According to Trezek, Wang and Paul (2010), "Most children who are deaf or hard of hearing experience significant auditory and oral language delay and have 'fewer' vocabularies than their hearing peers even with the use of amplification, sign language and special intervention" (p. 124). All these facts obviously reveal how much significance must be placed to the vocabulary teaching regarding students who are deaf and hard of hearing.

\subsubsection{Vocabulary development of deaf people}

Vocabulary development of deaf and hard of hearing learners, like the other linguistic aspects, is also not the same as their hearing peers. According to Kirk and Gallagner, "the average vocabulary 
amount of deaf learner during the period from age 8 to 18 is as much as the average hearing learner does between the beginning of kindergarten and the latter part of the second grade" (as cited in Hyjánková, 2010, p. 313). Because of the lack of hearing, hearing impaired learners have great difficulty in learning new words through an incidental learning process which their hearing peers have. Singleton, Morgan, DiGello, Wiles and Rivers (2004), in their experimental study, surveyed vocabulary use by low, moderate, and high ASL-Proficient writers in comparison to hearing ESL and monolingual speakers. The main aim of the study was to investigate the writing samples that they gathered from hearing and deaf students in terms of the vocabulary use. The vocabulary analysis embodied the following measures: function words, unique words, frequent words, and total words. The results of the study indicated that access to the distributional frequencies of English vocabulary is most likely decreased for almost all deaf children, and these children cannot learn and use new words as well as their hearing peers. It is also claimed that proficiency in American Sign Language can provide a new entry point for learning and using of English vocabulary.

Parents of deaf children also play a vital role in vocabulary development of their children. GoldinMeadow and Mayberry (2001) explain that "the frequency of informal, everyday language interactions between parents and children is the best predictor of language development, and by age 3, at least 95\% of a child's vocabulary has come from his parents" (p. 94). Furthermore, teachers of deaf learners have very significant effects in their vocabulary development. Therefore, the development procedures of vocabulary learning should be known and paid adequate attention by their parents and teachers so as to support the developmental process even through informal communication.

Moreover, Dimling (2007) also suggests three factors which influence the vocabulary development of deaf learners as "frequency of word use by parents, visual accessibility (signs, facial cues, or lips for speech reading need to be seen in order to be learned), and contingency (contingent naming or labeling objects when the child is attending to them)" (p. 21). As previously explained, parents are the first and most significant factor for the native language acquisition, and it gains more importance for the deaf and hard of hearing people since their native language is not the same language in the society they were born. To add, if the parents of deaf children know the national sign language which will be the mother tongue of their children, they will considerably facilitate their first language acquisition. Visual accessibility can be seen as one of the most significant factors due to their lack of acoustic input as well.

\subsubsection{Using visual techniques in teaching deaf learners}

Visual techniques stand for the techniques in which lots of visual materials such as drawings, wall charts, pictures, puppets, photographs, graphs, flashcards, crossword puzzles, picture stories, flannelboard, wheel charts, realia in the classroom, diagrams, figurines, mime, maps, advertisements, forms, films, gestures and facial expressions, magazine and newspaper cut-outs are used by the teacher. Thanks to the visual demonstrations, learners can associate the material presented in a meaningful way and correct the words in their minds. In addition, with technological developments, it is now easier to find and utilize the visual and authentic materials in the foreign language of learners, and so visual materials can easily be integrated with the audial elements. Therefore, audiovisual materials begin to be the most suitable materials for both learners and teachers.

As Dotter (2008) notes, "Because of its immediate connection to cognition and communication, language learning is the most crucial issue for deaf or hard of hearing” (p. 97). Vocabulary knowledge is also the most significant component in learning a foreign language. Hence, teaching vocabulary must be considered as the most important component of foreign language teaching for deaf and hard of hearing learners. Sign language instruction and visual techniques should be the most accurate techniques regarding the learning preferences of hearing impaired learners. As noted in the literature, 
these learners need to see in order to learn. They should see the forms of what they should learn because of not hearing. Dotter (2008) enlightens that "As the acoustic channel is more or less closed to deaf people, all acoustic data have to be presented in a visual form in order to be accessible" (p. 99). Hyjánková (2010) also espouses by saying, "Material stimulating visual perception is thought to be essential for education of the hearing impaired pupils. A serious hearing loss totally prevents handicapped pupils or students from auditory perception during lessons and that is why visuals have evidently a dominant role in language teaching to deaf learners" (p. 26). Deaf or hard of hearing people can easily learn concrete words with visual aids, yet abstract words are the most difficult ones to teach because visual representation is sometimes impossible for them. Using drama techniques and sign language instruction may be useful for such items.

Considering teaching foreign language vocabulary to deaf learners, it is a certain fact that language teachers ought to use effective and appropriate teaching techniques according to the needs of the learners. Davis (2000) summarizes the things to do by foreign language teachers of deaf learners. According to him, they should:

- "use visual materials as much as possible,

- focus on what the students can do,

- $\quad$ set up a positive language experience,

- break down the titles into small parts,

- use multiple examples,

- provide cultural comparisons,

- use different colours so as to attract the students' attention,

- try computer assisted language learning programs, and

- make use of cognates" (Davis, 2000).

As stated, it is a must for teachers of deaf and hard of hearing learners to use visual aids as much as possible. Vision becomes the primary means for deaf and hard of hearing learners to receive information. Therefore, they should consider using flashcards, posters, manipulatives, charts, graphic organizers, pictures, or any other visual items which they may find beneficial for their learners.

\subsection{Research questions}

The main aim of this study is to see if using visual materials together with a sign language is more effective on vocabulary recognition and retention than only using the sign language for the deaf students of EFL. For this purpose, the formulated research questions are as follows:

1. Did the experimental group show a statistically significant difference from the control group in terms of the immediate post-test?

2. Did the experimental group show a statistically significant difference from the control group in terms of the delayed post-test?

3. Is there a significant progress between the immediate post-test and delayed post-test scores of the control group?

4. Is there a significant progress between the immediate post-test and delayed post-test scores of the experimental group?

5. Is there a statistically significant difference between males and females in learning vocabulary by visual materials considering the results of immediate post-test and delayed post-test? 


\section{Method}

This experimental study is based upon an immediate post test and a delayed post test, which are applied to both the experimental group and the control group. The study attempts to explore the effectiveness of using visual materials together with the sign language in teaching vocabulary to deaf students who learn English as a foreign language. Teaching vocabulary through visual materials along with the sign language was compared to the teaching through just the sign language in order to decide which one is more effective for these learners. After teaching of the chosen vocabulary items, an immediate post-test was given, and delayed post-test was given six weeks later. The results of both tests were used to measure the effectiveness of visual materials and sign language on students' short term and long term retention. The study aimed to show whether using visual materials together with the sign language is more effective on vocabulary learning than using just sign language for the deaf learners who are at the starter level of English. Furthermore, whether there was a gender factor was investigated by comparing the scores of both groups from the immediate and delayed post-tests as well.

\subsection{Participants}

The study was conducted at a state special education vocational high school in Turkey. Firstly, an experimental and a control group were randomly formed so as to answer the research questions. Both groups consisted of 40 students. All 80 students were volunteer participants. Of the 80 participants included in the study, 31 (38.8\%) were male and 49 (61.2\%) were female Turkish deaf learners of EFL (Table 1).

Table 1. Number of Participants and Percentage of Males and Females

\begin{tabular}{llcc}
\hline & & Count & Table N \% \\
\hline \multirow{2}{*}{ Group } & Control Group & 40 & $50.0 \%$ \\
\cline { 2 - 4 } & Experimental Group & 40 & $50.0 \%$ \\
\hline \multirow{2}{*}{ Gender } & Female & 49 & $61.2 \%$ \\
\cline { 2 - 4 } & Male & 31 & $38.8 \%$ \\
\hline
\end{tabular}

When the study was conducted, all the students were at the beginner level of English since primary schools for hearing impaired students do not have English classes in Turkey. The students were between the ages of $15-18$, and they were all $9^{\text {th }}$ grade students. Students at special education vocational high schools have elective English classes for 9th and 10th grades and vocational foreign language classes for 10th grades. When this study was carried out, the students participated to the study took 3 hours of elective English classes a week. The participants were informed about the treatment that would be conducted in their classrooms before the study, and the researcher asked for their participation. New vocabulary items were presented to the experimental group by using various visual materials together with their sign language; and the control group was presented the same vocabulary items by just using the sign language of the learners, which is Turkish Sign language. The control group was not presented any visual materials; they were solely given sign language equivalents during the teaching process. 


\subsection{Data collection instruments}

Pre-test was not given to the participants since it is known that in primary schools for deaf students in Turkey, English classes are not available in the curriculum, so they were all at the starter level of English. After the treatment of the study, an immediate post-test was applied. This test consisted of five parts, and all parts were contextual. Cronbach Alpha test was utilized to ascertain the reliability of tests, and Table 2 indicates the results which prove that the tests are extremely reliable (Cronbach Alpha coefficient is > .70.).

Table 2. Reliability Statistics of Immediate and Delayed Post-tests

\begin{tabular}{lll}
\hline \multicolumn{2}{c}{ Cronbach's Alpha } & N of Items \\
\hline .974 & 2 & \\
\hline
\end{tabular}

Six weeks later, the same post test was given to the participants to measure the students' six-week retention of the words both for recognition and recall. The researcher gave the test to the participants and explained the instructions about the questions via their sign language. 40 minutes were given to the participants to complete.

\subsubsection{Instructional material}

In the study, the researcher utilized 50 new vocabulary items during the treatment. None of the participants had learned these words before. Concrete nouns were chosen as target vocabulary items to be able to use real objects and visual materials during the teaching process. Vocabulary items were divided into five different categories. The experimental group were introduced all vocabulary items through the medium of visual materials and real objects together with the sign language. The teacher tried to use these visual materials as much as possible during the teaching process. The same new words were introduced through just the sign language for the control group. The researcher did not use any visual materials in teaching new words to these learners.

\subsubsection{Testing material}

In this empirical study, the testing material was a vocabulary test which was used both as an immediate and delayed post-test. The test was crosschecked by two colleagues, and it was developed and used only for the study. There were five sections in the text. In the first part, the participants were expected to match the pictures with the words given. In the next part, they were asked to fill in the missing letters to complete the words. In the third part, which was designed as multiple choice questions, the participants were asked to choose the correct words for the pictures given. In the next part, the participants were expected to unscramble and write the correct words. In the last part, the participants were expected to write the correct words under the pictures. In grading, part 1, part 2 and part 3 were given 1 point, and the last two parts were given 2 points. Distractors were chosen from the remaining target words for the validity of the study. The test included all 50 target vocabulary items. The delayed post-test was conducted to evaluate 6 week-retention. All the tests were conducted and graded by the researcher. The participants were not enlightened about the test results at the end of the study.

\subsection{Data collection procedures}

This experimental study was conducted in two groups with the participation of 80 students. Participants were randomly chosen to form the control and the experimental groups. Each group consisted of 40 students, and the researchers planned to teach 50 target vocabulary items during the 
treatment. The students were at the starter level of English, and so they were not given a pre-test. Different visual materials and the sign language of the learners were utilized in the experimental group in order to present new target words. The sign language instruction was merely utilized in teaching the control group. A vocabulary test was implemented to evaluate both immediate and delayed results of the treatment. Just after the treatment, the first post-test was given to the participants, and the same test was applied as the delayed post-test to gauge the long term retention 6 weeks later.

Before the treatment, the researcher informed all participants about the experiment and she asked for their participation. The teaching process lasted 5 weeks. Each week, 10 new words were presented to each group. While teaching these words to the experimental group, the teacher provided a number of visual materials. The control group was taught only using the sign language of the students. They were not presented any visuals materials in order to compare the effectiveness of visual materials. All 50 new words were divided into ten groups which are fruits, vegetables, drinks, feelings, animals, kitchen, clothes, jobs, food and body parts. Each week, two group of words were chosen to teach to all the participants.

After the groups were presented all target vocabulary items, the researcher conducted immediate post-test to both groups so as to evaluate the recognition of the vocabulary items by the participants. 6 weeks later, the same test was given as the delayed post-test to gauge long-term retention. The participants were given 40 minutes for each test, and the researcher evaluated the results of the tests. The whole experimental process was at the natural classroom setting because the researcher was their English teacher at that time.

\subsection{Data analysis}

The results of immediate and delayed post-tests were systematically evaluated by using a computer program called "Statistical Package for the Social Sciences" (SPSS) Version 20.0. Independent Samples t-test was utilized for parametric samples to compare the experimental and the control group regarding immediate and delayed post-tests. Moreover, Paired Samples t-test was utilized to analyze the performances of the control group in terms of immediate and delayed post-tests scores. This test was also utilized to analyze all the scores of the experimental group. Lastly, Independent Samples ttest was utilized to analyze gender differences. The test results for both groups were compared to see the effectiveness of visual materials and the sign language statistically.

\section{Results and Discussion}

This experimental study aims to explore to what extent using visual materials together with the sign language is beneficial in teaching vocabulary to deaf students who learn English as a foreign language. It also aims to measure whether these materials are superior to using only sign language instructions. In this part, the comparison of the students' success and the scores of all tests were presented and evaluated concerning the research questions of the study.

\subsection{Research question 1}

This research question interrogates whether a significant difference exists between the experimental and the control groups regarding the immediate post-test scores. To answer the question, the test scores have been analyzed via Independent Samples t-test. As Table 3 and 4 indicate, regarding immediate post-test statistically significant difference between the control group and the experimental group has been observed (Sig. 2 tailed < .05). The results indicate that the experimental group $(\mathrm{M}=34,07$, $\mathrm{SD}=10,17)$ is more successful than the control group $(\mathrm{M}=28,12, \mathrm{SD}=9,79)$. As mentioned earlier, 
immediate post-test was given to two groups after the treatment. The experimental group was taught all new words by using visual aids together with the sign language although the control group was taught just via the sign language of the learners. These results prove that visual materials are very effective in teaching vocabulary to deaf students who learn English as a foreign language, which is the main concern of the study.

Table 3. Independent Samples T-test for Immediate Post-test Regarding Both Groups

\begin{tabular}{|c|c|c|c|c|c|c|c|c|c|c|}
\hline & & Leven & s Test & & & t-test & for Equality & of Means & & \\
\hline & & $\mathrm{F}$ & Sig. & $\mathrm{t}$ & $\mathrm{df}$ & $\begin{array}{l}\text { Sig. }(2- \\
\text { tailed) }\end{array}$ & $\begin{array}{c}\text { Mean } \\
\text { Difference }\end{array}$ & $\begin{array}{l}\text { Std. Error } \\
\text { Difference }\end{array}$ & $\begin{array}{r}95 \% \mathrm{Cc} \\
\text { Interv } \\
\text { Diff }\end{array}$ & $\begin{array}{l}\text { of the } \\
\text { ence }\end{array}$ \\
\hline & & & & & & & & & Lower & Upper \\
\hline & $\begin{array}{l}\text { Equal } \\
\text { variances } \\
\text { assumed }\end{array}$ & ,078 & ,781 & $-2,666$ & 78 & .009 & $-5,95000$ & 2,23222 & $\begin{array}{r}- \\
10,3940 \\
0\end{array}$ & $-1,50600$ \\
\hline Immpt & $\begin{array}{l}\text { Equal } \\
\text { variances } \\
\text { not } \\
\text { assumed }\end{array}$ & & & $-2,666$ & 77,887 & .009 & $-5,95000$ & 2,23222 & $\begin{array}{r}10,3941 \\
0\end{array}$ & $-1,50590$ \\
\hline
\end{tabular}

Table 4. Immediate Post-test Results of Both Groups

\begin{tabular}{rllcrr}
\hline Group & $\mathrm{N}$ & Mean & $\begin{array}{c}\text { Std. } \\
\text { Deviation }\end{array}$ & $\begin{array}{c}\text { Std. Error } \\
\text { Mean }\end{array}$ \\
\hline \multirow{2}{*}{ Immpt } & CG & 40 & 28,1250 & 9,79060 & 1,54803 \\
\cline { 2 - 6 } & EG & 40 & 34,0750 & 10,17132 & 1,60823 \\
\hline
\end{tabular}

\subsection{Research question 2}

The second research question examines the difference between the experimental and the control groups regarding the delayed post-test. Independent Samples t-test was applied to answer the question. The results of this test indicates, regarding delayed post-test, a statistically significant difference between the control group and the experimental group, which is shown in Table 5 and Table 6 (Sig. 2 tailed <.05). Thus, it is understood that the participants in the treatment group $(\mathrm{M}=33,95, \mathrm{SD}=10,09)$ did not forget the new words in 6-week-time. Moreover, these students were found to be more successful than the control group $(M=24,57, S D=9,55)$ in remembering the words they learnt. This result concluded that in vocabulary teaching to deaf learners of EFL, using visual materials together with the sign language is very effective in the long-term retention. 
Table 5. Independent Samples T-test for Delayed Post-test Regarding Both Groups

\begin{tabular}{|c|c|c|c|c|c|c|c|c|}
\hline & & $\begin{array}{l}\text { Leven } \\
\text { for } \mathrm{Eq} \\
\quad \text { Var }\end{array}$ & $\begin{array}{l}\text { 's Test } \\
\text { ality of } \\
\text { inces }\end{array}$ & & $\mathrm{t}$-test & for Equality & of Means & \\
\hline & & $\mathrm{F}$ & Sig. & df & $\begin{array}{l}\text { Sig. }(2- \\
\text { tailed) }\end{array}$ & $\begin{array}{c}\text { Mean } \\
\text { Difference }\end{array}$ & $\begin{array}{l}\text { Std. Error } \\
\text { Difference }\end{array}$ & $\begin{array}{c}95 \% \text { Confidence } \\
\text { Interval of the } \\
\text { Difference }\end{array}$ \\
\hline & & & & & & & & Lower Upper \\
\hline & $\begin{array}{l}\text { Equal } \\
\text { variances } \\
\text { assumed }\end{array}$ & ,037 & $, 848-4,264$ & 78 & .000 & $-9,37500$ & 2,19873 & $\begin{array}{cr}- & - \\
13,75233 & 4,99767\end{array}$ \\
\hline Dlypt & $\begin{array}{l}\text { Equal } \\
\text { variances } \\
\text { not } \\
\text { assumed }\end{array}$ & & $-4,264$ & 77,766 & .000 & $-9,37500$ & 2,19873 & $\begin{array}{cr}- & - \\
13,75254 & 4,99746\end{array}$ \\
\hline
\end{tabular}

Table 6. Delayed Post-test Results of Both Groups

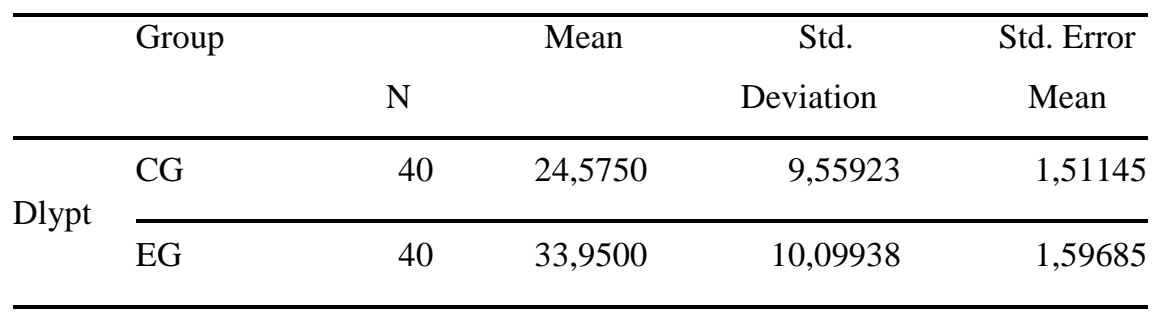

\subsection{Research question 3}

This question examines whether a statistically significant difference exists between the immediate post-test and delayed post-test scores of the participants in the control group. Delayed post-test was applied six weeks after the treatment to see the effects of sign language on long term retention in teaching vocabulary to deaf learners. Paired Samples T-test was applied (Table 7) in order to test this research question, and the mean difference is given below (Table 8). When the results of this test are examined, it is seen that the experimental group is more successful (sig 2 tailed $<.05$ ) than the control group. The results statistically show that the results of the immediate $(\mathrm{M}=28,12, \mathrm{SD}=9,79)$ and delayed post-test $(\mathrm{M}=24,57, \mathrm{SD}=9,55)$ are not identical. This difference is regarded as statistically insignificant. Since delayed post-test scores are lower than immediate post-test scores, this is a meaningful result. Therefore, it can be concluded that deaf learners of EFL are less successful regarding long-term retention if their sign language is utilized as an only means of instruction.

Table 7. Paired Samples T-test for Immediate and Delayed Post-tests of the Control Group

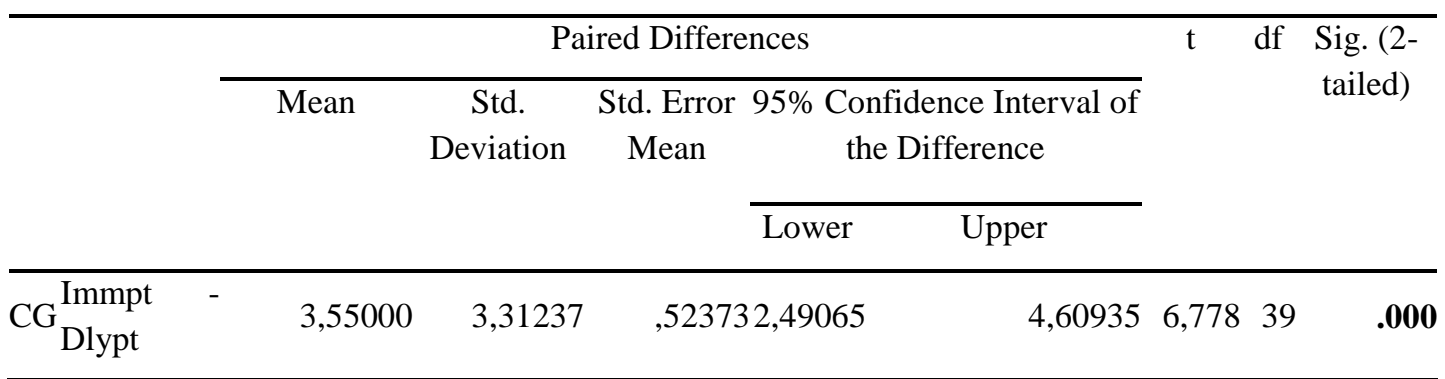


Table 8. Immediate and Delayed Post-test Results of the Control Group

\begin{tabular}{cccccc}
\hline & Mean & & \multicolumn{2}{c}{$\begin{array}{c}\text { Std. } \\
\text { Deviation }\end{array}$} & $\begin{array}{c}\text { Std. Error } \\
\text { Mean }\end{array}$ \\
\hline \multirow{2}{*}{ CG } & Immpt & 28,1250 & 40 & 9,79060 & 1,54803 \\
\cline { 2 - 5 } & & & & & 1,51145 \\
\hline
\end{tabular}

\subsection{Research question 4}

This research question interrogates whether there is a significant difference between the immediate post-test and delayed post-test scores of the participants in the treatment group. To answer this research question, Paired Samples t-test was utilized. The statistical values of immediate and delayed post-tests are illustrated in Table 9 and 10 below. According to these results, the treatment group shows statistically similar performances on the immediate $(\mathrm{M}=34,07, \mathrm{SD}=10,17)$ and delayed $(\mathrm{M}=33,95, \mathrm{SD}=10,09)$ post-tests, and there is no statistically significant difference among the participants' scores (sig 2 tailed $>.05$ ). Thus, it can be concluded that the participants did not forget the new words in 6-week-time. It is clear that for deaf learners of EFL, visual based vocabulary teaching techniques are very effective in the long-term retention.

Table 9. Paired Samples T-test for Immediate and Delayed Post-tests of the Experimental Group

\begin{tabular}{|c|c|c|c|c|c|c|c|c|}
\hline & & & & Paired Dif & ferences & & $\mathrm{t} \quad \mathrm{df}$ & Sig. (2- \\
\hline & & Mean & $\begin{array}{c}\text { Std. } \\
\text { Deviation }\end{array}$ & $\begin{array}{l}\text { Std. Error } \\
\text { Mean }\end{array}$ & $\begin{array}{r}95 \% \text { Confidenc } \\
\text { the Diffe }\end{array}$ & $\begin{array}{l}\text { nterval of } \\
\text { nce }\end{array}$ & & \\
\hline & & & & & Lower & Upper & & \\
\hline EG & $\begin{array}{l}\text { Immpt } \\
\text { Dlypt }\end{array}$ & - 12500 & 2,51343 & ,39741 &,- 67883 & ,9288. & 31539 & .755 \\
\hline
\end{tabular}

Table 10. Immediate and Delayed Post-test Results of the Experimental Group

\begin{tabular}{|c|c|c|c|c|c|}
\hline & & Mean & $\mathrm{N}$ & $\begin{array}{c}\text { Std. } \\
\text { Deviation }\end{array}$ & $\begin{array}{l}\text { Std. Error } \\
\text { Mean }\end{array}$ \\
\hline \multirow{2}{*}{ EG } & Immpt & 34,0750 & 40 & 10,17132 & 1,60823 \\
\hline & Dlypt & 33,9500 & 40 & 10,09938 & 1,59685 \\
\hline
\end{tabular}

\subsection{Research question 5}

This research question interrogates whether a significant difference exists between males and females in terms of both post tests. Independent Samples t-test was applied to the mean scores of the treatment and the control groups (Table 11, Table 12) to answer this question and the results indicate that there is no statistically significant difference between male $(\mathrm{M}=-2,16, \mathrm{SD}=3,16)$ and female $(\mathrm{M}=-$ $1,63, \mathrm{SD}=3,54$ ) participants (sig 2 tailed $>.05$ ). Therefore, it can be claimed that gender is not a significant factor in learning new words for deaf learners who learn English as a foreign language. 
Table 11. Independent Samples T-test for Gender Differences

\begin{tabular}{|c|c|c|c|c|c|c|c|c|c|}
\hline & \multicolumn{3}{|c|}{$\begin{array}{c}\text { Levene's Test for } \\
\text { Equality of } \\
\text { Variances }\end{array}$} & \multicolumn{5}{|c|}{ t-test for Equality of Means } & \\
\hline & \multirow[t]{2}{*}{$\mathrm{F}$} & \multirow[t]{2}{*}{ Sig. } & \multirow[t]{2}{*}{$\mathrm{t}$} & \multirow[t]{2}{*}{$\mathrm{df}$} & \multirow[t]{2}{*}{$\begin{array}{l}\text { Sig. }(2- \\
\text { tailed })\end{array}$} & \multirow[t]{2}{*}{$\begin{array}{c}\text { Mean } \\
\text { Difference }\end{array}$} & \multirow[t]{2}{*}{$\begin{array}{l}\text { Std. Error } \\
\text { Difference }\end{array}$} & \multicolumn{2}{|c|}{$\begin{array}{c}95 \% \text { Confidence Interval } \\
\text { of the Difference }\end{array}$} \\
\hline & & & & & & & & Lower & Upper \\
\hline $\begin{array}{l}\text { Equal variances } \\
\text { assumed } \\
\mathrm{PD}\end{array}$ &, 010 & & 920,677 & 78 & .501 &, 52864 &, 7810 & 1,02640 & 2,08367 \\
\hline $\begin{array}{l}\text { Equal variances } \\
\text { not assumed }\end{array}$ & & & ,6956 & 9,284 & .490 &, 52864 &, 7611 &,- 98968 & 2,04696 \\
\hline
\end{tabular}

Table 12. Comparison of Males and Females

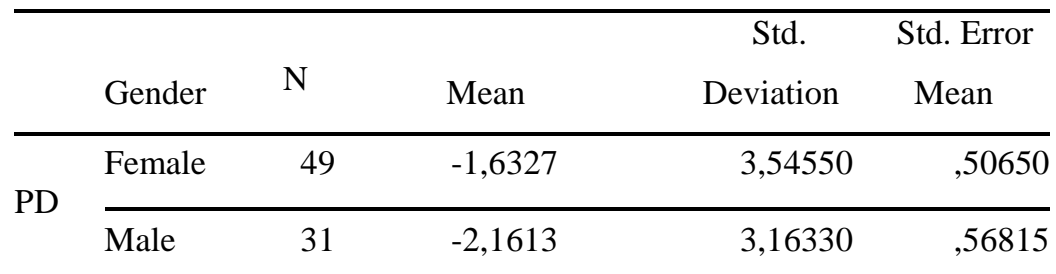

Table 13 and Table 14 below indicate the overall statistical differences of the performances of the groups more clearly and confirm that a significant statistical difference exists between the experimental $(\mathrm{M}=-, 12, \mathrm{SD}=2,51)$ and the control $(\mathrm{M}=-3,55, \mathrm{SD}=3,31)$ group regarding performance (sig 2 tailed < .05). It reveals that the treatment group indicated better performances regarding both recognition and long term retention of 50 target words. In addition to this, these results prove the effectiveness of visual materials in teaching deaf learners of EFL than using solely sign language.

Table 13. Independent Samples T-test for Performance Differences of Both Groups

\begin{tabular}{|c|c|c|c|c|c|c|c|c|c|}
\hline & \multicolumn{2}{|c|}{$\begin{array}{c}\text { Levene's Test for } \\
\text { Equality of } \\
\text { Variances }\end{array}$} & \multicolumn{7}{|c|}{ t-test for Equality of Means } \\
\hline & \multirow[t]{2}{*}{$\mathrm{F}$} & \multirow[t]{2}{*}{ Sig. } & \multirow[t]{2}{*}{$\mathrm{t}$} & \multirow[t]{2}{*}{$\mathrm{df}$} & \multirow[t]{2}{*}{$\begin{array}{l}\text { Sig. }(2- \\
\text { tailed) }\end{array}$} & \multirow[t]{2}{*}{$\begin{array}{c}\text { Mean } \\
\text { Difference }\end{array}$} & \multirow[t]{2}{*}{$\begin{array}{l}\text { Std. Error } \\
\text { Difference }\end{array}$} & \multicolumn{2}{|c|}{$\begin{array}{c}95 \% \text { Confidence Interval } \\
\text { of the Difference }\end{array}$} \\
\hline & & & & & & & & Lower & Upper \\
\hline $\begin{array}{l}\begin{array}{l}\text { Equal } \\
\text { variances }\end{array} \\
\text { PDsumed }\end{array}$ & 2,159 &, 146 & $-5,210$ & 78 & .000 & $-3,42500$ & ,65744 & $-4,73386$ & $-2,11614$ \\
\hline $\begin{array}{l}\text { Equal } \\
\text { variances not } \\
\text { assumed }\end{array}$ & & & $-5,210$ & 2,729 & .000 & $-3,42500$ & 65744 & $-4,73536$ & $-2,11464$ \\
\hline
\end{tabular}


Table 14. Comparison of Performance Differences

\begin{tabular}{|c|c|c|c|c|c|}
\hline & Group & $\mathrm{N}$ & Mean & $\begin{array}{c}\text { Std. } \\
\text { Deviation }\end{array}$ & $\begin{array}{l}\text { Std. Error } \\
\text { Mean }\end{array}$ \\
\hline \multirow{2}{*}{ PD } & CG & 40 & $-3,5500$ & 3,31237 & ,52373 \\
\hline & EG & 40 &,- 1250 & 2,51343 & ,39741 \\
\hline
\end{tabular}

\section{Conclusions}

Foreign language learning gains great importance for everyone to communicate effectively due to technological developments and globalization in today's world. The importance of vocabulary teaching is also increasing and because of being one of the most crucial elements in language teaching, the importance it deserves ought to be given by both language professionals and teachers. With regard to deaf and hard of hearing people, vocabulary is more prominent because they are not able to acquire all the components of a language owing to their impairment. Therefore, vocabulary teaching for deaf and hard of hearing people is vitally important in foreign language teaching and it should be given particular importance by language teachers.

There are several ways to teach vocabulary in foreign language teaching such as using visual materials, synonyms, definitions, mnemonics, guessing, opposites, etc. Learning styles of the learners must be taken into consideration in choosing the best teaching method. With regard to deaf and hard of hearing learners, teachers do not have a variety of techniques since they cannot hear and often speak. Thus, sign language instruction and visual materials such as flashcards, real objects etc. are some of the limited techniques they can use. In this experimental study, these two ways of teaching target vocabulary items were compared regarding deaf learners of EFL and it was investigated which one is superior in learning new words and long term retention as well. The instructor benefited from the native language equivalents of all new words in learners' sign language. It's usually sufficient for some foreign language learners, especially for adults, to learn the native language equivalents of the new words. Nonetheless, visual aids are essential for better vocabulary learning, especially for hearing impaired and deaf people. The statistical findings indicated that using visual materials together with the sign language is more effective than using only the sign language instruction because the treatment group made better progress in learning target vocabulary items and moreover, they outperformed the control group on long term retention. That is, visual technique provides better and permanent learning than using only the sign language instruction for deaf and hard of hearing learners. In addition, these learners learn and remember better when they are introduced new vocabulary items by using visual aids, which can be demonstrated with the test results of the study. It is clear that teaching via only sign language is effective in increasing the students' success level as well. Nonetheless, when compared, using visuals seems more effective for long-term retention. It can be concluded that the vocabulary teaching process should be enriched with the use of visuals as much as possible in teaching deaf learners of EFL, since this method can be used effectively for deaf learners who have poor linguistic memory but better visual memory in foreign language learning and other subjects as well.

In this experimental study, deaf students at the starter level of English were investigated. For further studies, different ages and levels may be explored. Furthermore, the scope of this study was just on vocabulary teaching. Visual materials may also be utilized for other language skills and components such as reading, grammar, writing, etc. and how they can be used in teaching these skills may also be explored and fostered. 
The study may support curriculum planners organize their curricula with regard to the needs of deaf and hard of hearing learners. Teachers of these learners may organize classroom activities with visual materials. It may also encourage their teachers to learn how to integrate these materials to the teaching processes.

\section{References}

Berent, G. P., \& Clymer, E. W. (2003). Use of instructional technologies to train international teachers of English to deaf students. Paper presented at the International Symposium on Instructional Technology and Education of the Deaf: Supporting Learners Preschool-College, National Technical Institute for the Deaf, Rochester Institute of Technology, Rochester, NY.

Berent, G. P., \& Clymer, E. W. (2007). Professional Development for Educators Teaching English for Academic Purposes to Deaf Students of English as a Foreign Language. The Postsecondary Education Network International. Retrieved from http://www.pen.ntid.rit.edu/newdownloads/ resources/documents/other/ EAPProfDev.pdf

Bidoli, C. J. K., \& Ochse, E. (Eds.). (2008). English in international deaf communication. Bern: International Academic Publishers.

Celce-Murcia, M., \& Rosensweig, F. (1989). Teaching vocabulary in the ESL classroom. In M. CelceMurcia \& L. McIntosh (Eds.). Teaching English as a second or foreign language (pp. 241-257). New York: Newbury House Publishers Inc.

Charrow, V. R., \& Fletcher, J. D. (1973). English as the second language of deaf children. Developmental Psychology, 10(4), 463-470.

Davis, C. D. (2000). Foreign language instruction: Tips for accommodating hard-of-hearing and deaf students. Washington, DC: Western Oregon University Press.

Dimling, L. M. (2007). Recognition, use, and comprehension of vocabulary by students who are deaf/hard of hearing: A strategic approach to vocabulary instruction. (Unpublished Doctoral dissertation). Michigan State University, Michigan, United States.

Dotter, F. (2008). English for deaf sign language users: Still a challenge. In K. Bidoli \& E. B. Ochse (Eds.), English in international deaf communication (pp.97-121). Bern: Peter Lang Publishing.

Flohr, S. (2008). Presenting and teaching vocabulary in the EFL classroom. Norderstedt: Grin Verlag.

Fowlkes, L. (2009). Vocabulary acquisition utilizing technology. Retrieved from http://faculty.rcoe.appstate.edu/koppenhaverd/s08/5040/papers/laurenf.pdf

Fromkin, V., Rodman, R., \& Hyams, N. (2011). An introduction to language. Boston, MA: Wadsworth Cengage Learning.

Goldin-Meadow, S., \& Mayberry, R. I. (2001). How do profoundly deaf children learn to read? Learning Disabilities Research and Practice, 16(4), 222-229. doi: 10.1111/0938-8982.00022

Hilzensauer, M., Skant, A. (2004). SignOn! - English for deaf sign language users on the internet. In C. J. K. Bidoli \& E. Ochse (Eds.) (2008), English in International Deaf Communication (pp. 155177). Bern: Peter Lang AG.

Hyjánková, E. (2010). Hearing impaired learners and their learning styles in English language classroom (Diploma Thesis). Masaryk University, Brno, Czech Republic. 
Kirk, S. A., \& Gallagher, J. J. (1989). Educating exceptional children. Boston, MA: Houghton Mifflin Company.

Lenneberg, E. H. (1967). Biological foundations of language. New York, NY: John Wiley.

Luckner, J. L, \& Cooke, C. (2010). A summary of the vocabulary research with students who are deaf or hard of hearing. American Annals of the Deaf, 155(1), pp.38-67.

Macurova, A. (2004). An introduction to principles of language learning. In D. Janakova (Ed.), Proceedings: Teaching English to deaf and hard of hearing students in secondary and tertiary levels of education in the Czech Republic (pp.28-41). Pragua, Czech Republic: Charles University.

Malmker, K. (Ed.). (1995). The linguistics encyclopedia. London: Routledge.

Martin, V. (2009). Language learning and deafness. (Bachelor Thesis). Masaryk University, Brno.

McCoy, K., \& Masterman, L. N. (1997). A tutor for teaching English as a second language for deaf users of American Sign Language. Paper presented at the Natural Language Processing for Communication Aids-An ACL/EACL Workshop, Madrid, Spain.

Pfau, R., Steinbach, M., \& Woll, B. (2012). Sign Language: An international handbook. Berlin: Walter de Gruyter GmbH \& Co.

Pohl, D. (2003). The teaching of vocabulary in the primary school foreign language classroom. Munich: Grin Verlag.

Singleton, J. L., Morgan, D., DiGello, E., Wiles, J., \& Rivers, R. (2004). Vocabulary use by low, moderate, and high ASL-proficient writers compared to hearing ESL and monolingual speakers. Journal of Deaf Studies and Deaf Education, (9)1, 86-103.

Trezek, B. J., Wang, Y., \& Paul, P. V. (2010). Reading and deafness: Theory, research and practice. Clfton Park, NY: Cengage Learning.

Wilbur, R. B. (2000). The use of ASL to support the development of English and literacy. Journal of Deaf Studies and Deaf Education, 5(1), 81-104.

Wilkins, D. A. (1972). Linguistics and language teaching. London: Edward Arnold.

\section{AUTHORS BIODATA}

Dr. Fatma Gülengül Birinci is received his B.A. and M.A. degree in English Language Teaching from Hacettepe University, and she completed her Ph.D. degree in Teaching Turkish as a Foreign Language from Hacettepe University. She is an instructor at School of Foreign Languages, Hacettepe University. Her professional interests are foreign language teaching, deaf learners of EFL, teaching English as a foreign language, teaching Turkish as a foreign language, distance education, and educational technologies in foreign language teaching.

Dr. Arif Sarıçoban has worked as an associate professor of ELT at Hacettepe University for 20 years and currently works at the Department of ELL at Selçuk University as a full professor. Dr. Sarıçoban is the editor-inchief for an international journal. 